\title{
Comprehensive analysis of PM20D1 QTL in Alzheimer's disease
}

\author{
Jose Vicente Sanchez-Mut ${ }^{*}$ (D, Liliane Glauser ${ }^{1}$, David Monk ${ }^{2,3}$ and Johannes Gräff ${ }^{*}$
}

\begin{abstract}
Background: Alzheimer's disease (AD) is a complex disorder caused by a combination of genetic and non-genetic risk factors. In addition, an increasing evidence suggests that epigenetic mechanisms also accompany AD. Genetic and epigenetic factors are not independent, but multiple loci show genetic-epigenetic interactions, the so-called quantitative trait loci (QTLs). Recently, we identified the first QTL association with AD, namely Peptidase M20 Domain Containing 1 (PM20D1). We observed that PM20D1 DNA methylation, RNA expression, and genetic background are correlated and, in turn, associated with AD. We provided mechanistic insights for these correlations and had shown that by genetically increasing and decreasing PM20D1 levels, AD-related pathologies were decreased and accelerated, respectively. However, since the PM20D1 QTL region encompasses also other genes, namely Nuclear Casein Kinase and Cyclin Dependent Kinase Substrate 1 (NUCKS1); RAB7, member RAS oncogene family-like 1 (RAB7L1); and Solute Carrier Family 41 Member 1 (SLC41A1), we investigated whether these genes might also contribute to the described AD association.

Results: Here, we report a comprehensive analysis of these QTL genes using a repertoire of in silico methods as well as in vivo and in vitro experimental approaches. First, we analyzed publicly available databases to pinpoint the major QTL correlations. Then, we validated these correlations using a well-characterized set of samples and locusspecific approaches-i.e., Sanger sequencing for the genotype, cloning/sequencing and pyrosequencing for the DNA methylation, and allele-specific and real-time PCR for the RNA expression. Finally, we defined the functional relevance of the observed alterations in the context of AD in vitro. Using this approach, we show that only PM20D1 DNA methylation and expression are significantly correlated with the AD-risk associated background. We find that the expression of SLC41A1 and PM20D1 - but not NUCKS1 and RAB7L1 - is increased in mouse models and human samples of AD, respectively. However, SLC41A1 and PM20D1 are differentially regulated by AD-related stressors, with only PM20D 1 being upregulated by amyloid- $\beta$ and reactive oxygen species, and with only PM20D1 being neuroprotective when overexpressed in cell and primary cultures.
\end{abstract}

Conclusions: Our findings reinforce PM20D1 as the most likely gene responsible of the previously reported PM20D1 QTL association with AD.

Keywords: Alzheimer, mQTL, eQTL, QTL, DNA methylation, RNA expression, PM20D1, SLC41A1, NUCKS1, RAB7L1

\section{Background}

Alzheimer's disease (AD) is the most common neurodegenerative disorder in western societies. It is characterized by a progressive decline in mental abilities, neuronal loss, and the accumulation of two types of protein aggregates, amyloid plaques and neurofibrillary

\footnotetext{
* Correspondence: jose.sanchezmut@epfl.ch; johannes.graeff@epfl.ch ${ }^{1}$ Laboratory of Neuroepigenetics, Brain Mind Institute, School of Life Sciences, Ecole Polytechnique Fédérale de Lausanne, CH-1015 Lausanne, Switzerland

Full list of author information is available at the end of the article
}

tangles [1]. The causes of AD remain elusive, but $\mathrm{AD}$ occurrence is currently understood as the consequence of a complex combination of genetic and non-genetic factors [2], the latter of which are believed to be mediated by epigenetic mechanisms $[3,4]$.

The genetic component of $\mathrm{AD}$ has been generally interrogated by genome-wide association studies (GWAS), which have identified an important number of risk loci associated with $\mathrm{AD}$ [5-7], but a causal relationship thereof remains difficult to establish. In contrast, the epigenetic contribution to $\mathrm{AD}$ is mainly interrogated by 
locus-specific or epigenome-wide association studies (EWAS) [8, 9], which have revealed site-specific epigenetic alterations and thereby provide mechanistic insights for a particular risk gene, but often lack the statistical power of GWAS [10]. Combining both approaches, it is now possible to identify single nucleotide polymorphisms (SNPs) that correlate with alterations in DNA methylation levels-the so-called methylation quantitative trait loci (mQTLs).

Recently, we reported the first mQTL association with $\mathrm{AD}$, which converges on the gene Predicted Metalloproteinase 20D1 (PM20D1) [11]. We have shown that AD-related cellular stressors-such as the presence of reactive oxygen species (ROS) and amyloid-beta $(\mathrm{A} \beta)$-increase PM20D1 expression, that $P M 20 D 1$ expression is upregulated in symptomatic $\mathrm{APP} / \mathrm{PS} 1 \mathrm{AD}$ mice and human $\mathrm{AD}$ samples, and that genetic manipulation of PM20D1 levels can modify the progression of the disease in APP/PS1 mice: When PM20D1 was overexpressed, disease progression was delayed; when PM20D1 was decreased, disease progression was accelerated.

At the same time, two high-throughput studies have expanded the PM20D1 expression QTL (eQTL) region, showing that the expression of neighboring genes to PM20D1 also correlate with several SNPs in that region, which include Nuclear Casein Kinase And Cyclin Dependent Kinase Substrate 1 (NUCKS1); RAB7, member RAS oncogene family-like 1 (RAB7L1); and Solute Carrier Family 41 Member 1 (SLC41A1), plus PM2OD1 $[12,13]$. Therefore, in spite of the reported functional validations for PM20D1 [11], we cannot completely exclude the possibility that these genes also contribute to the progression of $\mathrm{AD}$.

In the present study, we combine a series of in silico methods with in vivo and vitro experiments to provide a comprehensive analysis of PM20D1 eQTL genes, curated evidence for an AD association centered on PM20D1, and further support for the protective role of PM20D1 in $\mathrm{AD}$.

\section{Methods}

\section{DNA methylation and genetic background}

Hannon et al.'s mQTL database was interrogated for mQTLs-SNPs and CpGs-in each of the potential PM20D1 QTL region genes [14]. When significant, Bonferroni-corrected $p$ values were directly reported. mQTL SNPs were then investigated in our own postmortem human brain cohort of samples from the IDIBELL Biobank (Barcelona, Spain). DNA was isolated by phenol-chloroform extraction from gray matter of 18 control (Braak 0-II; 32\% female; age $64 \pm 3$ years, mean \pm SEM) and 21 Alzheimer's disease frontal cortex samples (Braak V-VI; 43\% female; age $77 \pm 2$ years, mean \pm
SEM). Genotypes were obtained by Sanger sequencing using primers listed in Additional file 1: Table S1. DNA was bisulfite converted using the EZ DNA methylation kit (Zymo Research), and tested for bisulfite cloning/sequencing and pyrosequencing as previously described [11]. Bisulfite conversion was ensured by including nonCG cytosines in the dispensation sequence following the manufacturer's instructions. Primers for bisulfite cloning/sequencing and pyrosequencing are listed in Additional file 1: Table S1.

\section{RNA expression and genetic background}

GTEX [12] and LIBD [13] datasets were investigated for eQTL correlations in each of the potential PM20D1 QTL region genes. When significant, FDR-corrected $p$ values were directly reported. Only previously annotated genes were considered for LIBD prefrontal (PFC) and hippocampal (Hip) datasets-i.e., Type = "Gene," Class = "InEns"; and Type =all, Class = "InGen," respectively. eQTL SNPs were then investigated in our cohort of samples. RNA purification was performed using TRIzol (Invitrogen), reverse-transcribed using the Thermoscript RT-PCR system (Invitrogen), and tested using StepOnePlus Real-Time PCR System (Applied Biosystems) and SYBR Green PCR MasterMaster Mix (Applied Biosystems). Three housekeeping genes were used for normalizing PCR signals. Primers for real-time PCR are listed in Additional file 1: Table S1.

The GeneNetwork database (http://www.genenetwork. org) was also analyzed for the PM20D1 QTL region genes in the $\mathrm{BxD}$ mice population. $\mathrm{BxD}$ mice derive from multiple intercrosses of the $\mathrm{C} 57 \mathrm{BL} / 6 \mathrm{~J}$ (B) and $\mathrm{DBA} / 2 \mathrm{~J}(\mathrm{D})$ progenitor mice, later inbred to fix the generated genetic variation [15]. To date, close to $200 \mathrm{BxD}$ strains have been generated and extensively characterized-at genetic, transcriptomic, and phenotypic levels (http://www.genenetwork.org/) - which constitutes a well-established genetic reference for the analysis of QTLs [16]. The eQTL analysis was performed using the BxD recombinant inbred (RI) Family group, Liver mRNA type, EPFL/LISP BXD CD Liver Affy Mouse Gene 1.0 ST (Apr13) RMA Exon Level dataset, with the interval mapping for the entire genome [16]. Images from GeneNetwork Map Viewer are represented.

\section{QTL expression in Alzheimer's disease}

PM20D1 QTL region gene expression was investigated in the aforementioned human brain cohort and five 12-month-old APP/PSEN1 [17] and five wild-type littermate male mouse frontal cortex samples. All animals were maintained under standard animal house conditions in a 12-h dark-light cycle with free access to food and water. The experimental procedures were conducted according to EPFL's and Switzerland's 
guidelines on animal welfare (cantonal animal experimentation authorization numbers VD2875.1 and VD3169).

\section{Functional validation}

SH-SY5Y neuroblastoma cells (ATCC) were cultured in DMEM supplemented with $20 \% \mathrm{FBS}, 100 \mu / \mathrm{ml}$ penicillin, and $100 \mathrm{mg} / \mathrm{ml}$ streptomycin at $37^{\circ} \mathrm{C}$ in a humidified atmosphere of $5 \% \mathrm{CO}_{2}$. SH-SY5Y cells were treated with $0.2 \%$ hydrogen peroxide (Merck) and with synthetic amyloid- $\beta$ (1-42)-derived diffusible ligands (ADDLs) (Abcam) during $6 \mathrm{~h}$ and $24 \mathrm{~h}$. Cell viability was measured using Alamarblue cell viability assay (Invitrogen) according to the manufacturer's instructions. Primary hippocampal neuron-glia co-cultures derived from P0 wild-type mice were cultured in media consisting of Neurobasal (Invitrogen), B27 supplement (Invitrogen), L-glutamine (Invitrogen), and penicillin/streptomycin (Invitrogen) (0.2 $\mathrm{ml}$ per well) on 96 -well plates $\left(2.5 \times 10^{4}\right.$ cells per well $)$ coated with Cultrex poly-L-lysine (Trevigen). Cells were infected at DIV6 with $20 \times 10^{3}$ (200 ng/well) viral particles containing either a GFP (mock) or a PM20D1/SLC41A1 version of the pLVX-IRES-ZsGreen1vector (Promega). At DIV 14-17, cytotoxicity was assessed using the CytoTox96 non-radioactive cytotoxicity assay (PROMEGA) according to the manufacturer's instructions.

\section{Statistical analysis}

The analyses were performed using Prism 6.0 (GraphPad). Correlations were calculated using Pearson's correlation coefficients, and comparisons using one-way ANOVA with post hoc Holm-Sidak's multiple comparison tests. $p$ values smaller than 0.05 were considered statistically significant and provided in the figures as follows: ${ }^{*} p<0.05,{ }^{* * *} p<0.01,{ }^{* * * *} p<0.005$, and ${ }^{* * * * *} p<0.0001$.

\section{Results}

DNA methylation and genetic background

PM20D1 DNA methylation is strongly correlated with the rs708727-rs960603 haplotype, and both, methylation and haplotype, are associated with AD [11] (Fig. 1a). In particular, multiple CpG sites in the PM20D1 promoter show strong correlations with rs1172198, rs708727, rs823082, rs823088, rs1361754, and rs960603 mQTL SNPs [14] (Table 1). Our previous whole-genome bisulfite sequencing (WGBS) analysis discarded similar correlations with PM20D1 neighboring genes [11]. However, since the eQTL region has been recently expanded in other tissues, which now also include the genes NUCKS1, RAB7L1, and SLC41A1 [12, 13] (Table 2), we cannot completely rule out the possibility that these genes show similar correlations. In particular, the GTEX consortium [12] found correlations between these particular mQTLs and the levels of RNA expression for
NUCKS1, RAB7L1, and SLC41A1 in the cerebellum; for PM20D1 in the hippocampus; and for NUCKS1, RAB7L1, SLC41A1, and PM20D1 in other non-brain tissues (e.g., blood, tibial nerve) [12]. In addition, the LIBD study [13] found correlations for RAB7L1, SLC41A1, and $P M 20 D 1$ in the dorsolateral prefrontal cortex, and for RAB7L1 and PM20D1 in the hippocampus [13] (Table 2).

Hence, we have expanded our previous analysis and measured the levels of DNA methylation of these genes in a genetically well-characterized human cohort of brain samples by locus-specific bisulfite sequencing and pyrosequencing (Fig. 1b, c). We observed no significant correlations between NUCKS1, RAB7L1, and SLC41A1 DNA methylation levels and the genetic background (Fig. 1b, c). In fact, NUCKS1, RAB7L1, and SLC41A1 promoter regions remained largely unmethylated, independently of the genetic background (Fig. 1b). In contrast, PM20D1 DNA methylation was strongly correlated with the genetic background (Fig. 1b, c). Thus, despite of a previously reported slight correlation for SLC41A1, i.e., values ranging from 7 to $9 \%$ of DNA methylation [14] (Table 1), PM20D1 arises as the only gene in this QTL region that truly qualifies as $\mathrm{mQTL}$.

\section{RNA expression and genetic background}

Similar to DNA methylation, we analyzed the RNA expression levels of the PM20D1 QTL genes by allelespecific and real-time PCR (Fig. 1d, e). NUCKS1, $R A B 7 L 1$, and $S L C 41 A 1$ were found to be expressed from both chromosomes (Fig. 1d), and showed no significant correlation with the genetic background, although a trend for SLC41A1 was observed (Fig. 1e). In contrast, the expression levels of PM20D1 were significantly correlated with the genetic background, and PM20D1 was mainly expressed from non-methylated chromosomes (Fig. 1b, c).

To further explore the PM20D1 QTL region, we took advantage of the $\mathrm{BxD}$ mouse population [15], since mice and humans share a large number of synteny blocks [18], including the PM20D1 QTL locus. Supporting our previous results, similar relationships were also observed in the $\mathrm{BxD}$ population, i.e., no effect of the genetic background for Nucks1, Rab7l1, and Slc41a1, but a strong correlation for Pm20d1 (Fig. 2). Taken together, these results suggest that in both, human and mice, the strongest eQTL effect is centered on PM20D1 in the region under investigation.

\section{QTL expression in Alzheimer's disease}

Genes in close proximity tend to share common regulatory elements and to correlate in expression $[19,20]$. PM20D1 is upregulated in human and mouse samples of $\mathrm{AD}$ [11], which stipulates that its neighboring genes 
A

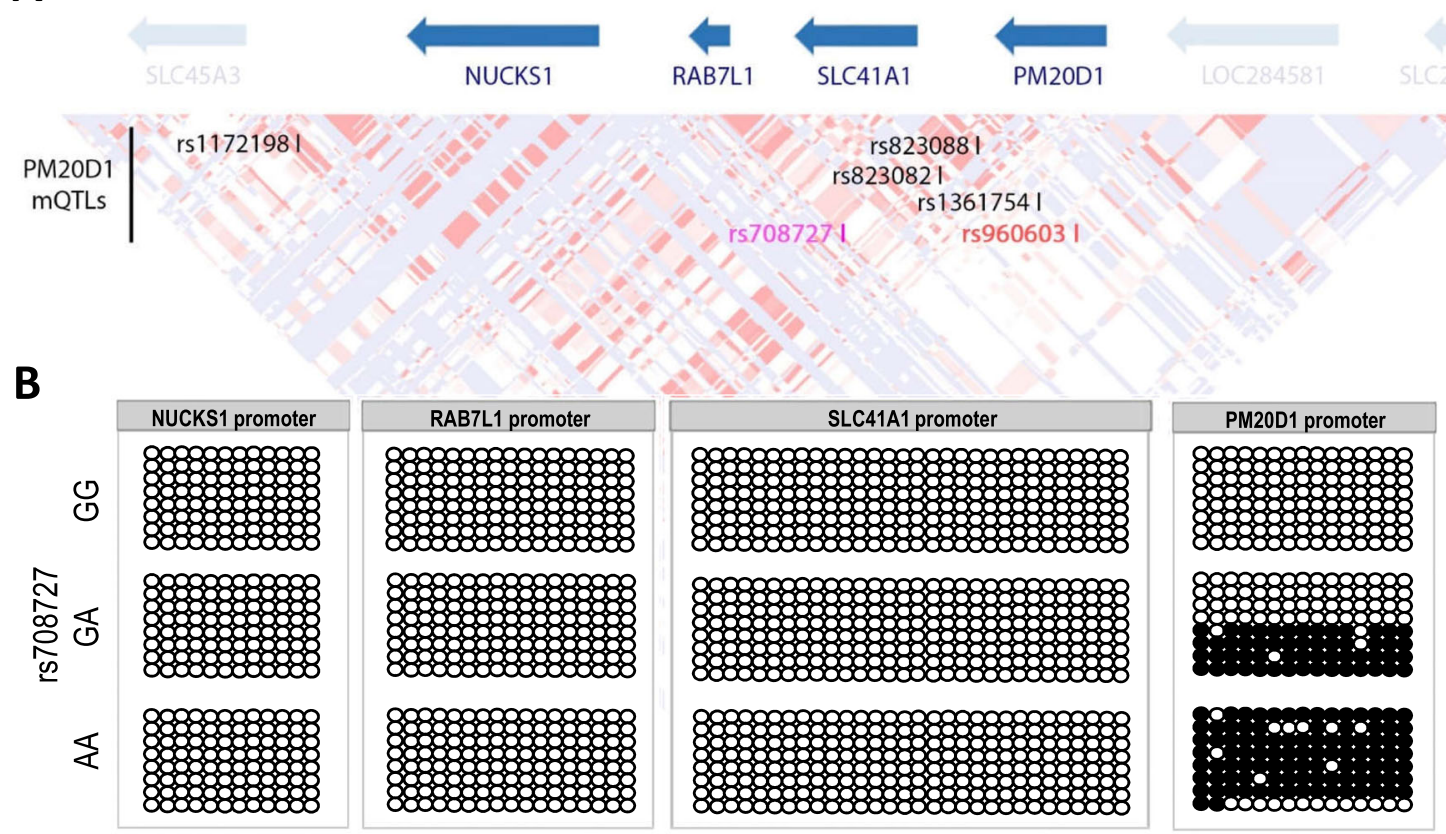

C
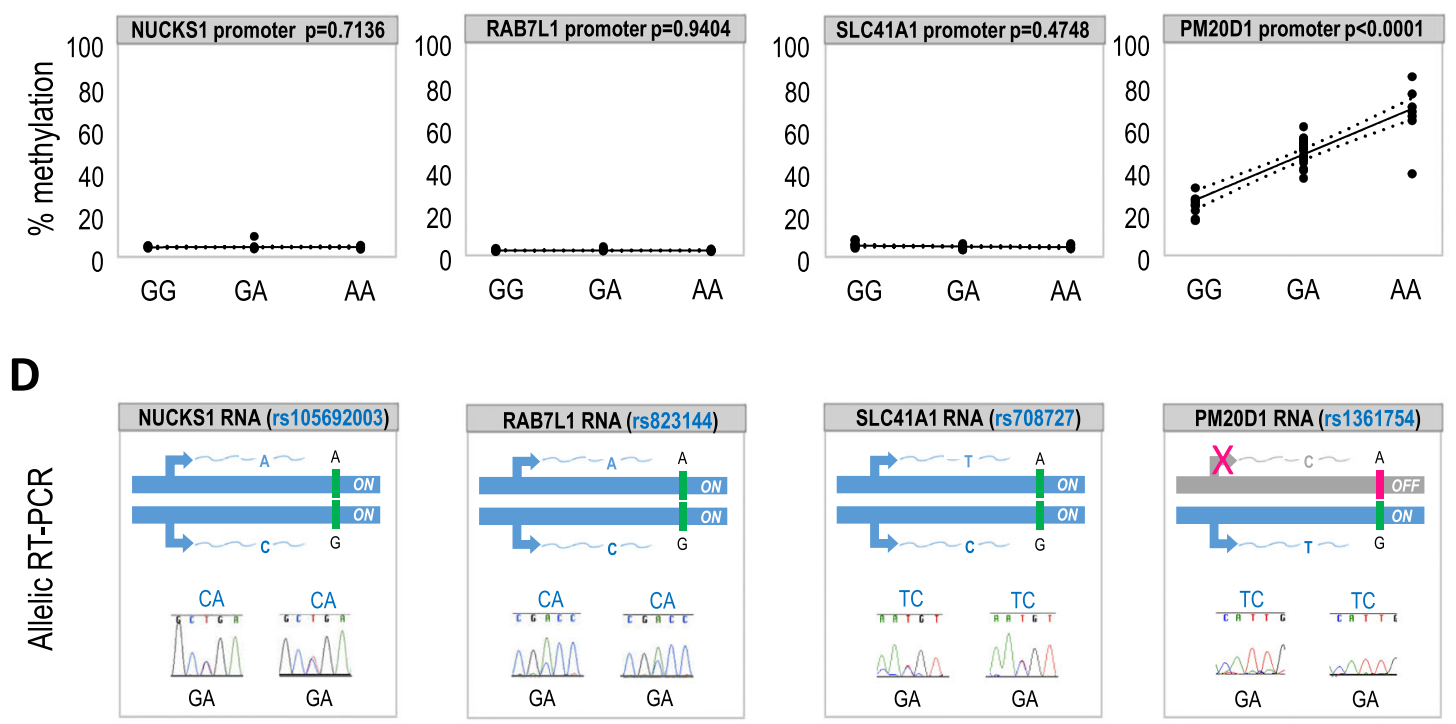

E
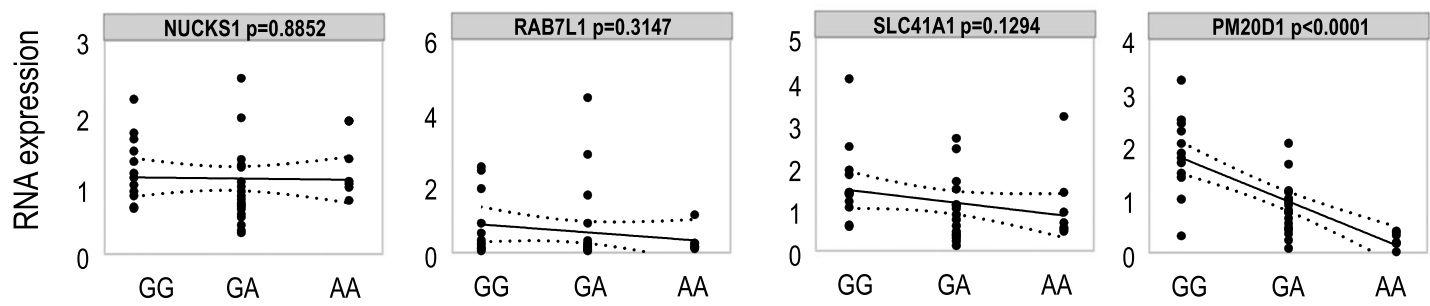

Fig. 1 (See legend on next page.) 
(See figure on previous page.)

Fig. 1 Overview of the full PM20D1 QTL region and its relation to AD in human frontal cortex. a The region comprises several genes (blue arrows) and is in partial linkage disequilibrium (HapMap CEU recombination map is indicated below the genes). PM20D1 mQTLs are indicated in black, of which the mQTLs most strongly associated with AD in bold magenta (rs708727) and bold red (rs960603) [11]. b Locus-specific bisulfite sequencing of PM20D1 QTL region genes. c rs708727 correlations with the levels of DNA methylation of PM20D1 QTL genes in human frontal cortex measured by pyrosequencing. d rs105692003, rs823144, rs708727, and rs1361754 are located in the coding region of NUCKS1, RAB7L1, SLC41A1, and PM20D1, respectively, and in linkage disequilibrium. Retrotranscription PCR Sanger sequencing of heterozygous samples detects RNA transcripts from both chromosomes for all genes, except for PM20D1 in which only one of the chromosomes is active. e rs 708727 correlates with the levels of RNA expression of PM20D1 QTL genes in human frontal cortex measured by qRT-PCR. Single values are represented by dots, $p$ values from Pearson's correlations

might be dysregulated in similar fashion. Accordingly, both SLC41A1 and PM20D1 eQTL low expression carriers seem to be associated with the same AD-risk haplotype (e.g., rs708727 AA carriers, Table 2 and Fig. 1e). To account for this possibility, we assessed the levels of expression of the PM20D1 QTL genes in APP/ PS1 mice and AD human postmortem samples, which were stratified by the rs708727 genotype. No significant expression differences were observed for NUCKS1 or $R A B 7 L 1$ in the frontal cortex of APP/PS1 mice at symptomatic stages (Fig. 3a), nor in human AD frontal cortex (Fig. 3b). Conversely, SLC41A1 levels were significantly increased in both APP/PS1 mice (Fig. 3a) and human AD samples, together with PM20D1 (Fig. 3b), which raises the question whether SLC41A1 might have similar neuroprotective functions as $P M 20 D 1$ or, alternatively, whether it participates of $\mathrm{AD}$ pathology.

\section{Functional validation}

To further disentangle the potential influence of PM20D1 QTL genes in AD, we next assayed their expression upon $A \beta$ and ROS exposure, two pathogenic hallmarks of $A D$ [2]. No significant differences were observed for NUCKS1 or RAB7L1 genes (Fig. 4a, b). Conversely, both $A \beta$ and ROS treatments significantly increased PM20D1 (Fig. 4a, b), while ROS but not $A \beta$ altered SLC41A1 expression, albeit in opposite direction (Fig. 4a, b). Of note, the expression of PM20D1 and SLC41A1 was expected to be positively correlated since both eQTLs are associated with the same AD-risk haplotype-i.e., they share common regulatory elements-and both genes are increased in mouse and human samples of AD. However, our results suggest that PM20D1 and SLC41A1 are regulated by different mechanisms since only PM20D1 is upregulated by AD-related stressorsi.e., $A \beta$ and ROS.

Lastly, to investigate whether SLC41A1, alongside with PM20D1 [11], might also influence AD progression, we overexpressed both genes in SH-SY5Y cells and primary neuronal cultures using lentiviral constructs, and assayed both ROS-induced cell death and cell viability. Confirming our previous results [11], PM20D1 overexpression decreased ROS-induced cell death (Fig. 4c) and increased cell viability (Fig. 4d). In contrast, SLC41A1 overexpression did not only not protect against ROSinduced cell death in SH-SY5Y cells (Fig. 4c), but instead proved to be detrimental per se (Fig. 4d), which is reminiscent of a previous report in which SLC41A1 overexpression was shown to reduce cell survival in multiple cell lines [21]. Counterintuitively, the AD-risk haplotype [11] is associated with lower levels of SLC41A1 expression, together with PM20D1, which seems to indicate

Table 1 PM20D1 mQTL region genes and SNPs and their DNA methylation correlation obtained from the Hannon database

\begin{tabular}{|c|c|c|c|c|c|c|c|c|c|c|}
\hline & $\mathrm{CpG}$ & rs1172198 & rs708727 & rs823082 & rs823088 & rs1361754 & rs960603 & Min & Max & Delta \\
\hline NUCKS1 & - & - & - & - & - & - & - & - & - & - \\
\hline RAB7L1 & - & - & - & - & - & - & - & - & - & - \\
\hline SLC41A1 & cg23034840 & - & 7.60E-08 & - & $2.90 \mathrm{E}-05$ & - & - & 7 & 9 & 2 \\
\hline PM20D1 & cg07157834 & - & $3.60 \mathrm{E}-22$ & - & - & - & - & 83 & 90 & 7 \\
\hline PM20D1 & cg24503407 & 4.60E-08 & $1.90 \mathrm{E}-25$ & $7.20 \mathrm{E}-16$ & - & $7.20 \mathrm{E}-16$ & $1.80 \mathrm{E}-12$ & 60 & 87 & 27 \\
\hline PM20D1 & cg07167872 & $2.80 \mathrm{E}-07$ & $5.00 \mathrm{E}-26$ & $7.00 \mathrm{E}-16$ & $4.10 \mathrm{E}-10$ & $6.90 \mathrm{E}-16$ & $1.90 \mathrm{E}-13$ & 41 & 79 & 38 \\
\hline PM20D1 & cg11965913 & $2.30 \mathrm{E}-11$ & $2.30 \mathrm{E}-37$ & $2.50 \mathrm{E}-19$ & $1.50 \mathrm{E}-10$ & $2.50 \mathrm{E}-19$ & $1.30 \mathrm{E}-14$ & 15 & 75 & 60 \\
\hline PM20D1 & cg14893161 & $1.30 E-12$ & 4.30E-34 & $7.00 \mathrm{E}-19$ & 1.30E-09 & $7.00 \mathrm{E}-19$ & $1.40 \mathrm{E}-13$ & 17 & 70 & 53 \\
\hline PM20D1 & cg14159672 & 1.30E-08 & $3.00 E-30$ & $3.20 \mathrm{E}-18$ & $1.20 \mathrm{E}-10$ & $3.20 \mathrm{E}-18$ & $3.10 E-13$ & 22 & 87 & 65 \\
\hline PM20D1 & cg26354017 & 1.40E-09 & $5.60 E-33$ & $2.10 \mathrm{E}-18$ & $4.50 \mathrm{E}-10$ & $2.10 \mathrm{E}-18$ & $1.10 \mathrm{E}-14$ & 12 & 83 & 71 \\
\hline PM20D1 & cg17178900 & 7.00E-08 & $1.20 \mathrm{E}-19$ & $1.20 \mathrm{E}-13$ & - & $1.20 \mathrm{E}-13$ & 4.10E-09 & 40 & 87 & 47 \\
\hline
\end{tabular}

Values represent CpG DNA methylation and SNP correlation Bonferroni-corrected $p$ values from Hannon et al. [14], $n=166$ prefrontal cortex samples (https:// epigenetics.essex.ac.uk/mQTL/). Min lowest value, Max highest value, Delta highest - lowest values. Significantly differentially probes for each gene are represented. "-," not significant 


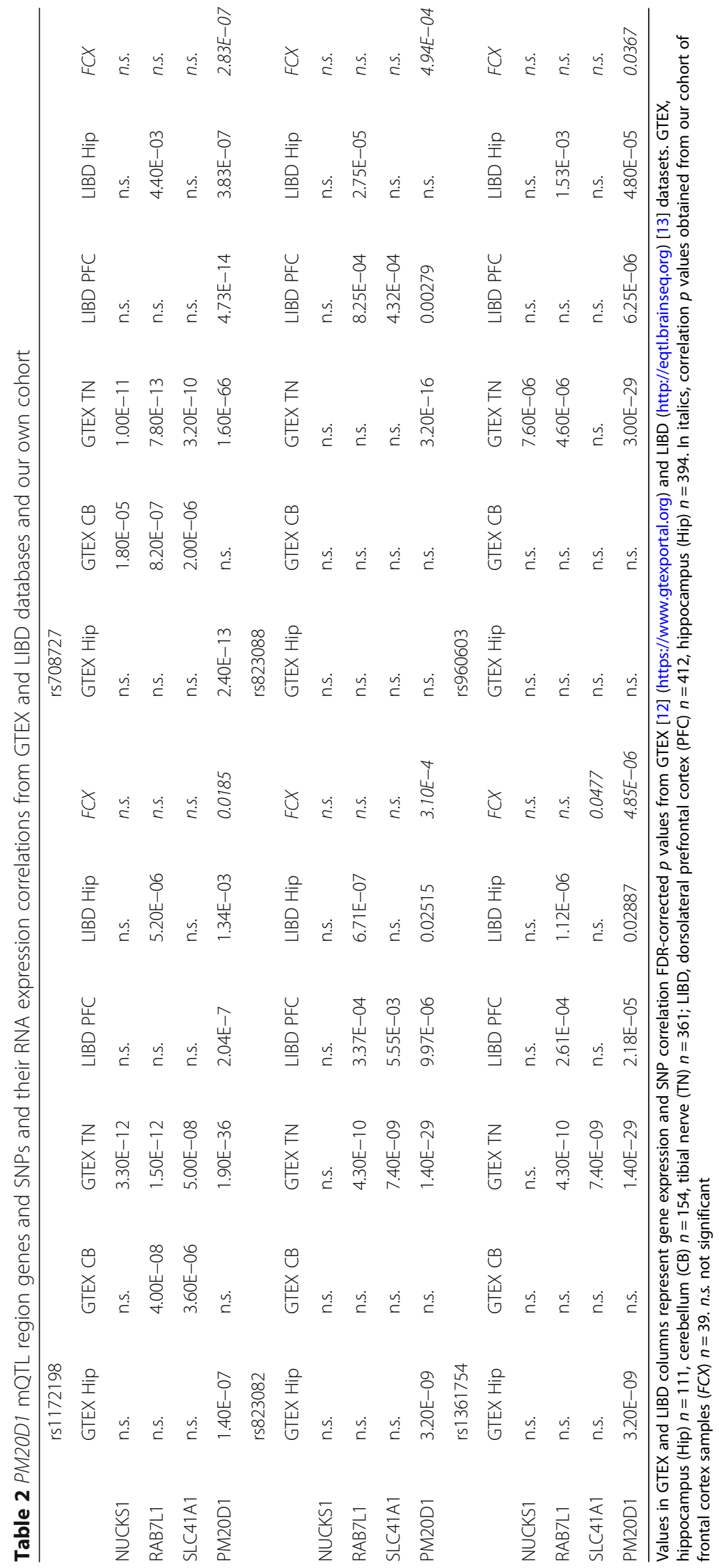




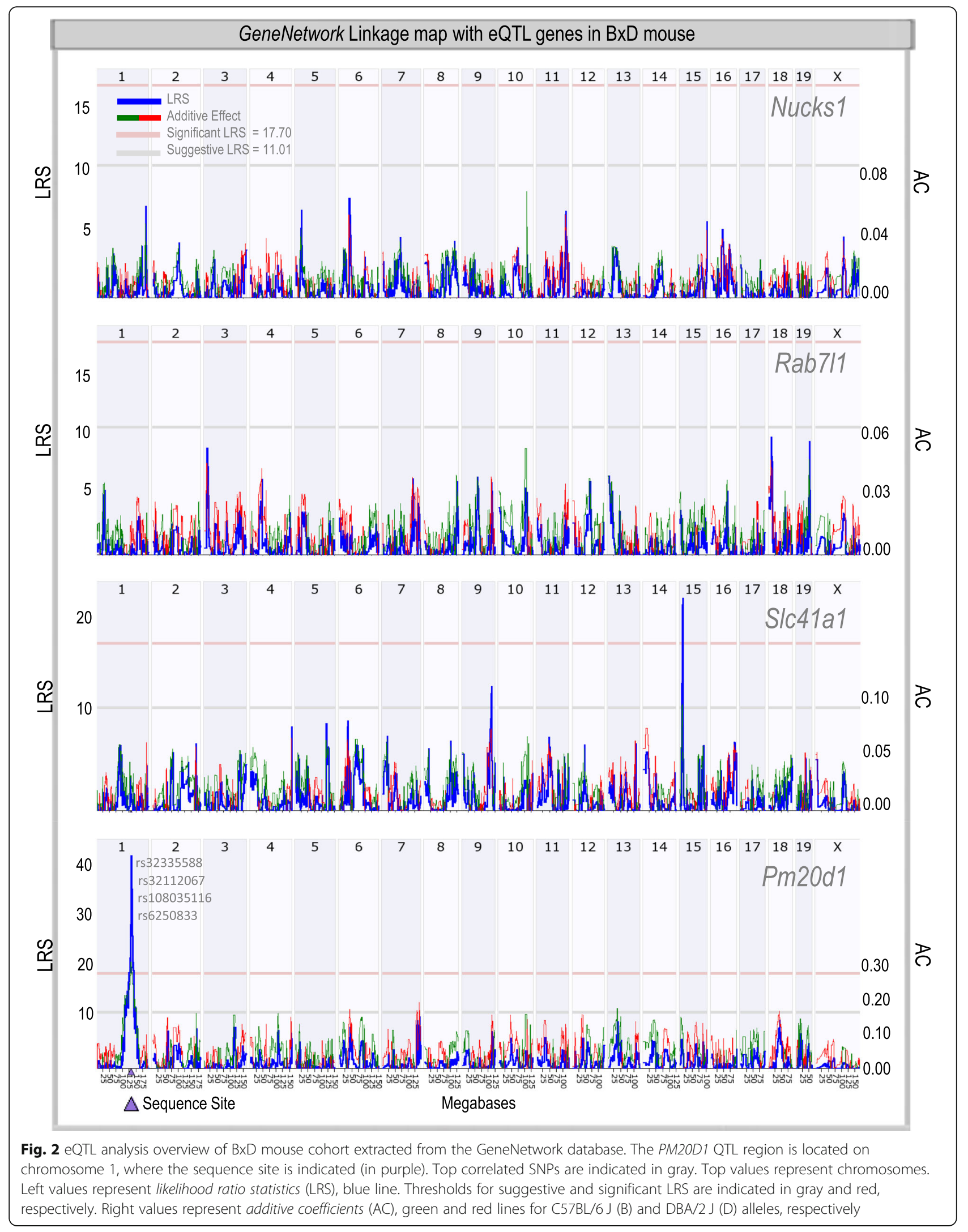



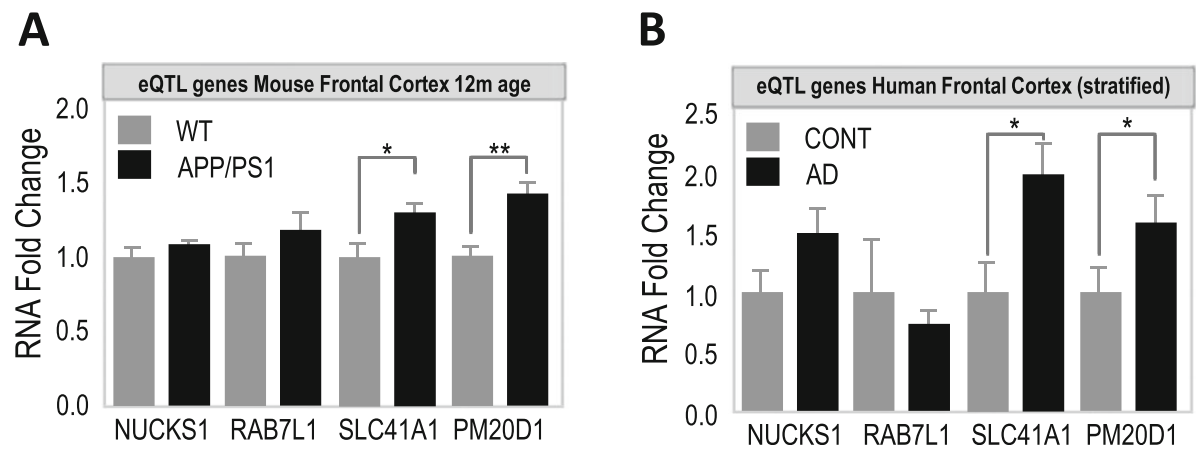

Fig. 3 Expression of PM20D1 QTL genes in AD. a Expression of PM20D1 QTL genes in human AD samples stratified by genotype. $\mathbf{b}$ Expression of PM20D1 QTL genes in APP/PS1 frontal cortex samples. Data are presented as means \pm SEM. ${ }^{*} p<0.05 ;{ }^{*} p<0.01$; one-way ANOVA, post hoc HolmSidak's multiple comparison test

that the epigenetic association with $\mathrm{AD}$ and the upregulation of SLC41A1 in AD are the consequence of different mechanisms.

In sum, these lines of evidence corroborate our previous results on PM20D1 and suggest that PM20D1-which is upregulated and protective in response to $\mathrm{AD}$-related stressors-is the main gene responsible of the AD-risk haplotype, while the evidence for SLC41A1 is less consistent and in a different direction.

\section{Discussion}

Our previous study has identified PM20D1 as a risk factor for AD [11]. We found that PM20D1 DNA methylation and RNA expression were correlated with the genetic background, which, in turn, was associated with AD. Moreover, we demonstrated that by genetically increasing and decreasing PM20D1 expression, AD-related pathologies were decreased and increased, respectively. Recently, the PM20D1 QTL region has been expanded to other genes, including NUCKS1, RAB7L1, and SLC41A1 genes [12, 13] (data shown in Table 2). These genes are in partial linkage disequilibrium with PM20D1 and, thereby, potentially contribute to our $\mathrm{AD}$ associated risk haplotype.

In order to test this hypothesis, we have performed a comprehensive analysis of PM20D1 QTL genes, at the DNA methylation, RNA expression, and functional level, using APP/PS1, human postmortem AD samples, as well as mouse in vivo and in vitro experiments. We found no significant correlations between the genetic background and the DNA methylation and/or RNA expression levels of other PM20D1 QTL genes, except for the previously reported PM20D1 itself (Fig. 1b-e, Fig. 2, Tables 1 and 2 ). This is in contrast to other studies, which, in addition to PM20D1, reported significant RNA expression correlations with the genetic background for NUCKS1, RAB7L1, and SLC41A1 (Table 2) [12, 13]. However, the strongest effects were found for rs708727 and PM20D1
DNA methylation, and for rs708727 and PM20D1 RNA expression in all datasets containing PM20D1, which pinpoints PM20D1 as the major QTL in the region (Tables 1 and 2). The reported discrepancies between these studies could lie in the power of the analysis, since the GTEX and LIBD studies contain bigger cohorts; different methods used, i.e., locus-specific versus the highthroughput approaches; and tissue- or brain regionspecific eQTL effects, for example, PM20D1 is not found in the cerebellum GTEX dataset. Consequently, whether PM20D1 is cell-type and/or tissue-specifically regulated will surely be a matter of future investigations.

Between control and AD samples, we observed no significant differences between the levels of RNA expression of PM20D1 QTL genes either, except for the previously reported PM20D1 and the newly reported SLC41A1, which were both increased in mouse and human samples of $A D$ (Fig. 3a, b). However, AD-related stressors such as $A \beta$ and ROS exclusively upregulated $P M 20 D 1$ expression, but not SLC41A1, which was either not affected or downregulated, respectively. In line with these results, only PM20D1 overexpression was found to protect against ROS-mediated cytotoxicity (Fig. 4c) and to increase cell viability (Fig. 4d), whereas SLC41A1 overexpression was either not protective (Fig. 4c) or even detrimental (Fig. 4d). These results are in concordance with other previous investigations. PM20D1 overexpression and depletion have been shown to be well tolerated [22, 23]. Both adeno-associated virus transduced [22] and PM20D1 knockdown [23] mice are viable and appear healthy, although these manipulations led to altered $\mathrm{N}$-acyl amino acid production, which affects thermogenesis regulation [22,23]. On the contrary, both the overexpression and the depletion of SLC41A1 have been found to be detrimental. SLC41A1 overexpression reduced cell survival in multiple cell lines [21], while morpholino-mediated depletion induced severe developmental abnormalities in zebrafish [24], which 
A

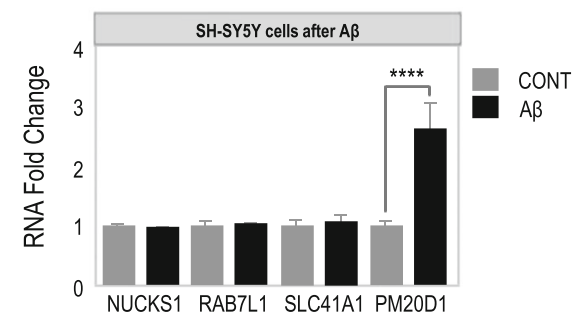

C

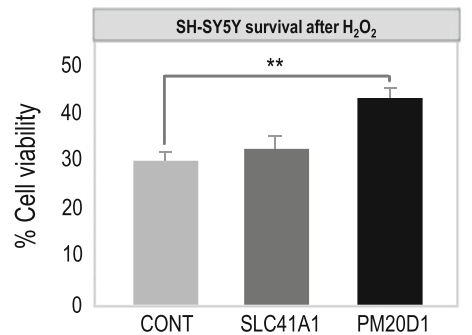

B

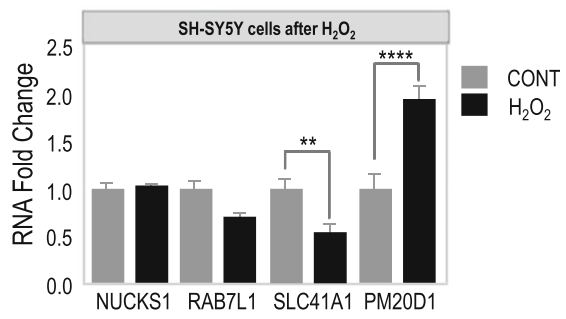

D

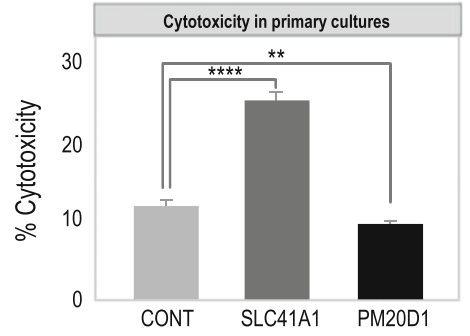

Fig. 4 Functional validation of PM20D1 QTL genes in vitro. a PM20D1 QTL gene expression in SH-SY5Y cells after A treatment. b PM20D1 QTL gene expression in SH-SY5Y cells after $\mathrm{H}_{2} \mathrm{O}_{2}$ treatment. c Cell viability of PM2OD1 and SLC41A1 overexpressing SH-SY5Y cells after $\mathrm{H}_{2} \mathrm{O}_{2}$ treatment. d PM20D1 and SLC41A1 overexpression cytotoxicity in primary cultures. Data are presented as means \pm SEM. ${ }^{*} p<0.05 ;{ }^{* *} p<0.01 ;{ }^{* * *} p<0.005$; ${ }^{* * * *} p<0.0001$; one-way ANOVA, post hoc Holm-Sidak's multiple comparison test

suggests the need of well-controlled levels of SLC41A1. Interestingly, both PM2OD1 and SLC41A1 are expressed by astrocytes [25] and might therefore be indirectly associated with increased levels of gliosis in $\operatorname{AD}[17,26]$. However, as the lack of expression of both PM20D1 and SLC41A1 is associated with a higher risk of AD, but only PM20D1 is upregulated by AD-related stressors and neuroprotective, this suggests that first, PM20D1 is the most relevant gene for $\mathrm{AD}$ within the analyzed loci, and second, that the increased levels of SLC41A1 in AD might be a mere consequence of the increased number of astrocytes.

Interestingly, PM20D1 has previously been shown to activate mitochondrial uncoupling [22], which promotes neuronal survival [27] and appears to be protective against neurodegenerative disorders including $\mathrm{AD}$ and Parkinson's disease (PD) [28]. Mitochondrial uncoupling plays important roles in the adaptive responses to bioenergetic and oxidative stressors. It decreases ROS production, prevents mitochondrial calcium accumulation, and regulates protein and substrate mitochondrial import [29]. In addition, PM20D1 itself has also been related to several disorders characterized by high levels of ROS, such as diabetes [22] and obesity [22], and to neurodegenerative diseases with strong mitochondrial alterations, including multiple sclerosis [30] and PD [31]. Taken together, these data suggest a potential use of PM20D1- derived treatment approaches not only for $\mathrm{AD}$, but likely also other diseases.

In sum, our results further support that PM20D1 is the most likely responsible candidate of the previously reported QTL association with $\mathrm{AD}$, and reinforce its protective role in AD. How precisely PM20D1 exerts its protective functions now requires further investigations.

\section{Supplementary information}

Supplementary information accompanies this paper at https://doi.org/10. 1186/s13148-020-0814-y.

Additional file 1: Table S1. List of primers used for the different techniques.

\section{Abbreviations}

AD: Alzheimer's disease; eQTL: Expression quantitative trait loci;

EWAS: Epigenome-wide association studies; GFAP: Glial fibrillary acidic protein; GWAS: Genome-wide association studies; MQTL: Methylation quantitative trait loci; NUCKS1: Nuclear Casein Kinase And Cyclin Dependent Kinase Substrate 1; PM20D1 : Peptidase M20 Domain Containing 1;

QTL: Quantitative trait loci; RAB7L1: RAB7, member RAS oncogene family-like 1; ROS: Reactive oxygen species; SLC41A1: Solute Carrier Family 41 Member 1; SNPs: Single nucleotide polymorphisms

\section{Acknowledgements}

We acknowledge Dr. Maroun Bou Sleiman and Prof. Johan Auwerx (EPFL, Lausanne, Switzerland) for their help with the GeneNetwork database.

\section{Authors' contributions}

JVS-M and JG conceived the project and designed the experiments. JVS-M, $L G$, and DM performed the experiments. JVS-M analyzed the data. DM and $J G$ contributed to the interpretation of the results. The paper was written by 
JVS-M and JG and commented on by all authors. All authors read and approved the final manuscript.

\section{Funding}

JVS-M is supported by a SYNAPSIS Foundation Advanced PostDocs fellowship and Heidi Seiler-Stiftung foundation. The laboratory of DM is supported by the Foundation Jérôme Lejeune, Spanish Ministerio de Educación y Competitividad (BFU2014-53093). The laboratory of DM is supported by Ministerio de Economía, Industria y Competitividad (MINECO), which is part of Agencia Estatal de Investigación (AEI), through the project BFU201785571-R (co-funded by the European Regional Development Fund; ERDF, a way to build Europe). The laboratory of JG is supported by the SYNAPSIS Foundation, the Béatrice Ederer-Weber Stiftung, the Floshield Foundation, and the Alzheimer's Association (NIRG-15-363964). JG is an MQ fellow and a NARSAD Independent Investigator.

\section{Availability of data and materials}

The datasets generated and analyzed during the current study are not publicly available but are available from the corresponding author on reasonable request.

\section{Ethics approval and consent to participate}

Postmortem tissues were obtained from the IDIBELL Biobank, which is part of the eBrainNet Europe Bank "Network of Excellence" funded by the European Commission in the 6th Framework Program "Life Science" (LSHMCT-2004-503039). Informed consent was obtained from all participants. The collection of all samples conforms to the relevant regulations, ethical considerations, and legislation as defined by the European Union.

\section{Consent for publication}

Not applicable.

\section{Competing interests}

JVS-M and JG hold a patent for the use of PM20D1 methylation and haplotype as biomarkers for Alzheimer's disease (European patent no. 16180434.9). The other authors declare that they have no competing interests.

\section{Author details}

${ }^{1}$ Laboratory of Neuroepigenetics, Brain Mind Institute, School of Life Sciences, Ecole Polytechnique Fédérale de Lausanne, CH-1015 Lausanne, Switzerland. ${ }^{2}$ Genomic Imprinting Cancer Group, Institut d'Investigació Biomedica de Bellvitge, E-08908 Barcelona, Spain. ${ }^{3}$ Biomedical Research Centre, School of Biological Sciences, University of East Anglia, NR4 7TJ Norwich, UK.

Received: 24 June 2019 Accepted: 15 January 2020

Published online: 03 February 2020

\section{References}

1. Cummings $J \mathrm{~L}$, Morstorf T, Zhong K. Alzheimer's disease drug-development pipeline: few candidates, frequent failures. Alzheimers Res Ther. 2014;6(4):37. https://doi.org/10.1186/alzrt269.

2. Holtzman DM, Goate A, Kelly J, Sperling R. Mapping the road forward in Alzheimer's disease. Sci Transl Med. 2011;3(114):114ps148. https://doi.org/10. 1126/scitranslmed.3003529.

3. Chouliaras L, Rutten BP, Kenis G, Peerbooms O, Visser PJ, Verhey F, van Os J, Steinbusch HW, van den Hove DL. Epigenetic regulation in the pathophysiology of Alzheimer's disease. Prog Neurobiol. 2010;90(4):498-510. https://doi.org/10.1016/j.pneurobio.2010.01.002.

4. Sanchez-Mut JV, Graff J. Epigenetic alterations in Alzheimer's disease. Front Behav Neurosci. 2015;9:347. https://doi.org/10.3389/fnbeh.2015.00347.

5. Scheltens P, Blennow K, Breteler MM, de Strooper B, Frisoni GB, Salloway S, Van der Flier WM. Alzheimer's disease. Lancet. 2016. https://doi.org/10.1016/ S0140-6736(15)01124-1.

6. Jansen IE, Savage JE, Watanabe K, Bryois J, Williams DM, Steinberg S, Sealock J, Karlsson IK, Hagg S, Athanasiu L, Voyle N, Proitsi P, Witoelar A, Stringer S, Aarsland D, Almdahl IS, Andersen F, Bergh S, Bettella F, Bjornsson S, Braekhus A, Brathen G, de Leeuw C, Desikan RS, Djurovic S, Dumitrescu L, Fladby T, Hohman TJ, Jonsson PV, Kiddle SJ, Rongve A, Saltvedt I, Sando SB,
Selbaek G, Shoai M, Skene NG, Snaedal J, Stordal E, Ulstein ID, Wang Y, White LR, Hardy J, Hjerling-Leffler J, Sullivan PF, van der Flier WM, Dobson R, Davis LK, Stefansson H, Stefansson K, Pedersen NL, Ripke S, Andreassen OA, Posthuma D. Genome-wide meta-analysis identifies new loci and functional pathways influencing Alzheimer's disease risk. Nat Genet. 2019;51(3):404-13. https://doi.org/10.1038/s41588-018-0311-9.

7. Kunkle BW, Grenier-Boley B, Sims R, Bis JC, Damotte V, Naj AC, Boland A, Vronskaya M, van der Lee SJ, Amlie-Wolf A, Bellenguez C, Frizatti A, Chouraki $V$, Martin ER, Sleegers K, Badarinarayan N, Jakobsdottir J, Hamilton-Nelson KL, Moreno-Grau S, Olaso R, Raybould R, Chen Y, Kuzma AB, Hiltunen M, Morgan T, Ahmad S, Vardarajan BN, Epelbaum J, Hoffmann P, Boada M, Beecham GW, Garnier JG, Harold D, Fitzpatrick AL, Valladares O, Moutet ML, Gerrish A, Smith AV, Qu L, Bacq D, Denning N, Jian X, Zhao Y, Del Zompo M, Fox NC, Choi SH, Mateo I, Hughes JT, Adams HH, Malamon J, SanchezGarcia F, Patel Y, Brody JA, Dombroski BA, Naranjo MCD, Daniilidou M, Eiriksdottir G, Mukherjee S, Wallon D, Uphill J, Aspelund T, Cantwell LB, Garzia F, Galimberti D, Hofer E, Butkiewicz M, Fin B, Scarpini E, Sarnowski C, Bush WS, Meslage S, Kornhuber J, White CC, Song Y, Barber RC, Engelborghs S, Sordon S, Voijnovic D, Adams PM, Vandenberghe R, Mayhaus M, Cupples LA, Albert MS, De Deyn PP, Gu W, Himali JJ, Beekly D, Squassina A, Hartmann AM, Orellana A, Blacker D, Rodriguez-Rodriguez E, Lovestone S, Garcia ME, Doody RS, Munoz-Fernadez C, Sussams R, Lin H, Fairchild TJ, Benito YA, Holmes C, Karamujic-Comic H, Frosch MP, Thonberg H, Maier W, Roschupkin G, Ghetti B, Giedraitis V, Kawalia A, Li S, Huebinger RM, Kilander L, Moebus S, Hernandez I, Kamboh MI, Brundin R, Turton J, Yang Q, Katz MJ, Concari L, Lord J, Beiser AS, Keene CD, Helisalmi S, Kloszewska I, Kukull WA, Koivisto AM, Lynch A, Tarraga L, Larson EB, Haapasalo A, Lawlor B, Mosley TH, Lipton RB, Solfrizzi V, Gill M, Longstreth WT Jr, Montine TJ, Frisardi V, Diez-Fairen M, Rivadeneira F, Petersen RC, Deramecourt V, Alvarez I, Salani F, Ciaramella A, Boerwinkle E, Reiman EM, Fievet N, Rotter Jl, Reisch JS, Hanon O, Cupidi C, Andre Uitterlinden AG, Royall DR, Dufouil C, Maletta RG, de Rojas I, Sano M, Brice A, Cecchetti R, George-Hyslop PS, Ritchie K, Tsolaki M, Tsuang DW, Dubois B, Craig D, Wu CK, Soininen H, Avramidou D, Albin RL, Fratiglioni L, Germanou A, Apostolova LG, Keller L, Koutroumani M, Arnold SE, Panza F, Gkatzima O, Asthana S, Hannequin D, Whitehead P, Atwood CS, Caffarra P, Hampel H, Quintela I, Carracedo A, Lannfelt L, Rubinsztein DC, Barnes LL, Pasquier F, Frolich L, Barral S, McGuinness B, Beach TG, Johnston JA, Becker JT, Passmore P, Bigio EH, Schott JM, Bird TD, Warren JD, Boeve BF, Lupton MK, Bowen JD, Proitsi P, Boxer A, Powell JF, Burke JR, Kauwe JSK, Burns JM, Mancuso M, Buxbaum JD, Bonuccelli U, Cairns NJ, McQuillin A, Cao C, Livingston G, Carlson CS, Bass NJ, Carlsson CM, Hardy J, Carney RM, Bras J, Carrasquillo MM, Guerreiro R, Allen M, Chui HC, Fisher E, Masullo C, Crocco EA, DeCarli C, Bisceglio G, Dick M, Ma L, Duara R, Graff-Radford NR, Evans DA, Hodges A, Faber KM, Scherer M, Fallon KB, Riemenschneider M, Fardo DW, Heun R, Farlow MR, Kolsch H, Ferris S, Leber M, Foroud TM, Heuser I, Galasko DR, Giegling I, Gearing M, Hull M, Geschwind DH, Gilbert JR, Morris J, Green RC, Mayo K, Growdon JH, Feulner T, Hamilton RL, Harrell LE, Drichel D, Honig LS, Cushion TD, Huentelman MJ, Hollingworth P, Hulette CM, Hyman BT, Marshall R, Jarvik GP, Meggy A, Abner E, Menzies GE, Jin LW, Leonenko G, Real LM, Jun GR, Baldwin CT, Grozeva D, Karydas A, Russo G, Kaye JA, Kim R, Jessen F, Kowall NW, Vellas B, Kramer JH, Vardy E, LaFerla FM, Jockel KH, Lah JJ, Dichgans M, Leverenz JB, Mann D, Levey Al, Pickering-Brown S, Lieberman AP, Klopp N, Lunetta KL, Wichmann HE, Lyketsos CG, Morgan K, Marson DC, Brown K, Martiniuk F, Medway C, Mash DC, Nothen MM, Masliah E, Hooper NM, McCormick WC, Daniele A, McCurry SM, Bayer A, McDavid AN, Gallacher J, McKee AC, van den Bussche $H_{\text {, }}$ Mesulam M, Brayne C, Miller BL, Riedel-Heller S, Miller CA, Miller JW, AlChalabi A, Morris JC, Shaw CE, Myers AJ, Wiltfang J, O'Bryant S, Olichney JM, Alvarez V, Parisi JE, Singleton AB, Paulson HL, Collinge J, Perry WR, Mead S, Peskind E, Cribbs DH, Rossor M, Pierce A, Ryan NS, Poon WW, Nacmias B, Potter H, Sorbi S, Quinn JF, Sacchinelli E, Raj A, Spalletta G, Raskind M, Caltagirone C, Bossu P, Orfei MD, Reisberg B, Clarke R, Reitz C, Smith AD, Ringman JM, Warden D, Roberson ED, Wilcock G, Rogaeva E, Bruni AC, Rosen HJ, Gallo M, Rosenberg RN, Ben-Shlomo Y, Sager MA, Mecocci P, Saykin AJ, Pastor P, Cuccaro ML, Vance JM, Schneider JA, Schneider LS, Slifer S, Seeley WW, Smith AG, Sonnen JA, Spina S, Stern RA, Swerdlow RH, Tang M, Tanzi RE, Trojanowski JQ, Troncoso JC, Van Deerlin VM, Van Eldik LJ, Vinters HV, Vonsattel JP, Weintraub S, Welsh-Bohmer KA, Wilhelmsen KC, Williamson J, Wingo TS, Woltjer RL, Wright CB, Yu CE, Yu L, Saba Y, 
Alzheimer Disease Genetics C, European Alzheimer's Disease I, Cohorts for $H$, Aging Research in Genomic Epidemiology C, Genetic, Environmental Risk in Ad/Defining Genetic P, Environmental Risk for Alzheimer's Disease C, Pilotto A, Bullido MJ, Peters O, Crane PK, Bennett D, Bosco P, Coto E, Boccardi V, De Jager PL, Lleo A, Warner N, Lopez OL, Ingelsson M, Deloukas P, Cruchaga C, Graff C, Gwilliam R, Fornage M, Goate AM, Sanchez-Juan P, Kehoe PG, Amin N, Ertekin-Taner N, Berr C, Debette S, Love S, Launer LJ, Younkin SG, Dartigues JF, Corcoran C, Ikram MA, Dickson DW, Nicolas G, Campion D, Tschanz J, Schmidt H, Hakonarson H, Clarimon J, Munger R, Schmidt R, Farrer LA, Van Broeckhoven C, COD M, AL DS, Jones L, Haines JL, Deleuze JF, Owen MJ, Gudnason V, Mayeux R, Escott-Price V, Psaty BM, Ramirez A, Wang LS, Ruiz A, van Duijn CM, Holmans PA, Seshadri S, Williams J, Amouyel P, Schellenberg GD, Lambert JC, Pericak-Vance MA. Genetic meta-analysis of diagnosed Alzheimer's disease identifies new risk loci and implicates Abeta, tau, immunity and lipid processing. Nat Genet. 2019;51(3): 414-30. https://doi.org/10.1038/s41588-019-0358-2.

8. Lunnon K, Smith R, Hannon E, De Jager PL, Srivastava G, Volta M, Troakes C, AlSarraj S, Burrage J, Macdonald R, Condliffe D, Harries LW, Katsel P, Haroutunian V, Kaminsky Z, Joachim C, Powell J, Lovestone S, Bennett DA, Schalkwyk LC, Mill J. Methylomic profiling implicates cortical deregulation of ANK1 in Alzheimer's disease. Nat Neurosci. 2014;17(9):1164-70. https://doi.org/10.1038/nn.3782.

9. De Jager PL, Srivastava G, Lunnon K, Burgess J, Schalkwyk LC, Yu L, Eaton ML, Keenan BT, Ernst J, McCabe C, Tang A, Raj T, Replogle J, Brodeur W, Gabriel S, Chai HS, Younkin C, Younkin SG, Zou F, Szyf M, Epstein CB, Schneider JA, Bernstein BE, Meissner A, Ertekin-Taner N, Chibnik LB, Kellis M, Mill J, Bennett DA. Alzheimer's disease: early alterations in brain DNA methylation at ANK1, BIN1, RHBDF2 and other loci. Nat Neurosci. 2014;17(9): 1156-63. https://doi.org/10.1038/nn.3786.

10. Rakyan VK, Down TA, Balding DJ, Beck S. Epigenome-wide association studies for common human diseases. Nat Rev Genet. 2011;12(8):529-41. https://doi.org/10.1038/nrg3000.

11. Sanchez-Mut JV, Heyn H, Silva BA, Dixsaut L, Garcia-Esparcia P, Vidal E, Sayols S, Glauser L, Monteagudo-Sanchez A, Perez-Tur J, Ferrer I, Monk D, Schneider B, Esteller M, Graff J. PM20D1 is a quantitative trait locus associated with Alzheimer's disease. Nat Med. 2018;24(5):598-603. https:// doi.org/10.1038/s41591-018-0013-y.

12. Consortium GT, Laboratory DA, Coordinating Center -Analysis Working G, Statistical Methods groups-Analysis Working G, Enhancing Gg, Fund NIHC, Nih/Nci, Nih/Nhgri, Nih/Nimh, Nih/Nida, Biospecimen Collection Source Site $\mathrm{N}$, Biospecimen Collection Source Site R, Biospecimen Core Resource V, Brain Bank Repository-University of Miami Brain Endowment B, Leidos Biomedical-Project M, Study E, Genome Browser Data I, Visualization EBI, Genome Browser Data I, Visualization-Ucsc Genomics Institute UoCSC, Lead a, Laboratory DA, Coordinating C, management NIHp, Biospecimen C, Pathology, e QTLmwg, Battle A, Brown CD, Engelhardt BE, Montgomery SB. Genetic effects on gene expression across human tissues. Nature. 2017; 550(7675):204-13. https://doi.org/10.1038/nature24277.

13. Jaffe AE, Straub RE, Shin JH, Tao R, Gao Y, Collado-Torres L, Kam-Thong T, Xi HS, Quan J, Chen Q, Colantuoni C, Ulrich WS, Maher BJ, Deep-Soboslay A, BrainSeq C, Cross AJ, Brandon NJ, Leek JT, Hyde TM, Kleinman JE, Weinberger DR. Developmental and genetic regulation of the human cortex transcriptome illuminate schizophrenia pathogenesis. Nat Neurosci. 2018;21(8):1117-25. https://doi.org/10.1038/s41593-018-0197-y.

14. Hannon E, Spiers H, Viana J, Pidsley R, Burrage J, Murphy TM, Troakes C, Turecki G, O'Donovan MC, Schalkwyk LC, Bray NJ, Mill J. Methylation QTLs in the developing brain and their enrichment in schizophrenia risk loci. Nat Neurosci. 2016;19(1):48-54. https://doi.org/10.1038/nn.4182.

15. Peirce JL, Lu L, Gu J, Silver LM, Williams RW. A new set of BXD recombinant inbred lines from advanced intercross populations in mice. BMC Genet. 2004;5:7. https://doi.org/10.1186/1471-2156-5-7.

16. Mulligan MK, Mozhui K, Prins P, Williams RW. GeneNetwork: a toolbox for systems genetics. Methods Mol Biol. 2017;1488:75-120. https://doi.org/10. 1007/978-1-4939-6427-7_4

17. Borchelt DR, Ratovitski T, van Lare J, Lee MK, Gonzales V, Jenkins NA, Copeland NG, Price DL, Sisodia SS. Accelerated amyloid deposition in the brains of transgenic mice coexpressing mutant presenilin 1 and amyloid precursor proteins. Neuron. 1997;19(4):939-45.

18. Pevzner P, Tesler G. Human and mouse genomic sequences reveal extensive breakpoint reuse in mammalian evolution. Proc Natl Acad Sci U S A. 2003;100(13):7672-7. https://doi.org/10.1073/pnas.1330369100.
19. Ghanbarian AT, Hurst LD. Neighboring genes show correlated evolution in gene expression. Mol Biol Evol. 2015;32(7):1748-66. https://doi.org/10.1093/ molbev/msv053.

20. Zhang J, Chen H, Li R, Taft DA, Yao G, Bai F, Xing J. Spatial clustering and common regulatory elements correlate with coordinated gene expression. PLoS Comput Biol. 2019;15(3):e1006786. https://doi.org/10.1371/journal.pcbi. 1006786.

21. Sponder G, Abdulhanan N, Frohlich N, Mastrototaro L, Aschenbach JR, Rontgen M, Pilchova I, Cibulka M, Racay P, Kolisek M. Overexpression of $\mathrm{Na}(+) / \mathrm{Mg}(2+)$ exchanger SLC41A1 attenuates pro-survival signaling. Oncotarget. 2018;9(4):5084-104. https://doi.org/10.18632/oncotarget.23598.

22. Long JZ, Svensson KJ, Bateman LA, Lin H, Kamenecka T, Lokurkar IA, Lou J, Rao RR, Chang MR, Jedrychowski MP, Paulo JA, Gygi SP, Griffin PR, Nomura DK, Spiegelman BM. The secreted enzyme PM20D1 regulates lipidated amino acid uncouplers of mitochondria. Cell. 2016;166(2):424-35. https:// doi.org/10.1016/j.cell.2016.05.071.

23. Long JZ, Roche AM, Berdan CA, Louie SM, Roberts AJ, Svensson KJ, Dou FY, Bateman LA, Mina Al, Deng Z, Jedrychowski MP, Lin H, Kamenecka TM, Asara JM, Griffin PR, Banks AS, Nomura DK, Spiegelman BM. Ablation of PM20D1 reveals $\mathrm{N}$-acyl amino acid control of metabolism and nociception. Proc Natl Acad Sci U S A. 2018;115(29):E6937-45. https://doi.org/10.1073/ pnas. 1803389115.

24. Hurd TW, Otto EA, Mishima E, Gee HY, Inoue H, Inazu M, Yamada $H$, Halbritter J, Seki G, Konishi M, Zhou W, Yamane T, Murakami S, Caridi G, Ghiggeri G, Abe T, Hildebrandt F. Mutation of the Mg2+ transporter SLC41A1 results in a nephronophthisis-like phenotype. J Am Soc Nephrol. 2013;24(6):967-77. https://doi.org/10.1681/ASN.2012101034.

25. Zhang Y, Chen K, Sloan SA, Bennett ML, Scholze AR, O'Keeffe S, Phatnani HP, Guarnieri P, Caneda C, Ruderisch N, Deng S, Liddelow SA, Zhang C, Daneman R, Maniatis T, Barres BA, Wu JQ. An RNA-sequencing transcriptome and splicing database of glia, neurons, and vascular cells of the cerebral cortex. J Neurosci. 2014;34(36):11929-47. https://doi.org/10. 1523/JNEUROSCI.1860-14.2014.

26. Serrano-Pozo A, Frosch MP, Masliah E, Hyman BT. Neuropathological alterations in Alzheimer disease. Cold Spring Harbor Perspectives Med. 2011; 1(1):a006189. https://doi.org/10.1101/cshperspect.a006189.

27. Perreten Lambert $H$, Zenger $M$, Azarias $G$, Chatton JY, Magistretti PJ, Lengacher S. Control of mitochondrial pH by uncoupling protein 4 in astrocytes promotes neuronal survival. J Biol Chem. 2014;289(45):31014-28. https://doi.org/10.1074/jbc.M114.570879.

28. Geisler JG, Marosi K, Halpern J, Mattson MP. DNP, mitochondrial uncoupling, and neuroprotection: a little dab'll do ya. Alzheimer's Dementia. 2017;13(5): 582-91. https://doi.org/10.1016/j.jalz.2016.08.001.

29. Wallace DC. A mitochondrial paradigm of metabolic and degenerative diseases, aging, and cancer: a dawn for evolutionary medicine. Annu Rev Genet. 2005;39:359-407. https://doi.org/10.1146/annurev.genet.39.110304. 095751.

30. Maltby VE, Lea RA, Sanders KA, White N, Benton MC, Scott RJ, Lechner-Scott J. Differential methylation at MHC in CD4(+) T cells is associated with multiple sclerosis independently of HLA-DRB1. Clin Epigenetics. 2017;9:71. https://doi.org/10.1186/s13148-017-0371-1.

31. Pihlstrom L, Rengmark A, Bjornara KA, Dizdar N, Fardell C, Forsgren $L$, Holmberg B, Larsen JP, Linder J, Nissbrandt H, Tysnes OB, Dietrichs E, Toft M. Fine mapping and resequencing of the PARK16 locus in Parkinson's disease. J Hum Genet. 2015;60(7):357-62. https://doi.org/10.1038/jhg.2015.34.

\section{Publisher's Note}

Springer Nature remains neutral with regard to jurisdictional claims in published maps and institutional affiliations. 